\title{
The Role of Faults on Tehran Alluvial and Its Impact on Resistance of Alluvial
}

\author{
Omid Asadzadeh Saghavaz ${ }^{1}$, Manouchehr Ghorashi' ${ }^{1}$, Mohsen Pourkermani ${ }^{1,2}$ \\ ${ }^{1}$ Islamic Azad University, North Tehran Branch, Tehran, Iran \\ ${ }^{2}$ Tectonic Group, Islamic Azad University, Tehran, Iran \\ Email: Omid.asadzadeh68@gmail.com, Ghorashi_manouchehr@yahoo.com,Mohsen.Pourkermani@gmail.com
}

How to cite this paper: Saghavaz, O.A., Ghorashi, M. and Pourkermani, M. (2017) The Role of Faults on Tehran Alluvial and Its Impact on Resistance of Alluvial. Open Journal of Geology, 7, 1128-1139. https://doi.org/10.4236/ojg.2017.78075

Received: May 30, 2017

Accepted: August 14, 2017

Published: August 17, 2017

Copyright ( 92017 by authors and Scientific Research Publishing Inc. This work is licensed under the Creative Commons Attribution International License (CC BY 4.0).

http://creativecommons.org/licenses/by/4.0/

Open Access

\begin{abstract}
Tehran is located in the Alborz's mountain range subsidence and alluvial deposits which are formed in the different faults. Though these faults caused changes in Northern Tehran's alluvium. The geomechanics factors on these alluviums made northern area of Tehran a dangerous place to construct. In this article we have tried to determine the zone's resistance [1], critical depth in excavation and in the end the role of faults in mechanical resistance of alluvium by comparing several pits in the zone of fault or the zone with no fault. For this purpose, the impact of the neighboring building on the pit stability has been investigated in several locations in some part of coarse alluvium of northern Tehran. So engineering methods such as numerical method and limit equilibrium with the help of software like FLAC and SLIDE were used to determine alluvium's resistance and the critical depth of excavation. It was done in a way that several pits were analyzed and evaluated in the studied area to a depth of 20 meters in the unloaded state of the neighboring buildings, and once even the load of a neighboring 5-storey building placed at a distance of 3 meters from the edge of the considered pit was analyzed and the results were compared.
\end{abstract}

\section{Keywords}

Mechanical Resistance, Faulting, Numerical Methods, Limit Equilibrium Method

\section{Introduction}

Tehran, with a population of more than 12 million, has experienced a rapid increase in population over the last three decades to become one of the largest cities in the Middle East [2]. Although faults and folds within Quaternary alluvial deposits of the Tehran plain were initially recognized in the 1950s (Rieben 1955), 
and have been the subject of multiple later studies (e.g. Tchalenko et al. 1974; Berberian, 1976; Berberian et al. 1985; Abbassi \& Farbod, 2009; Landgraf, 2010; Solaymani Azad et al. 2011). The expansion of the city over the last few decades has largely prevented characterization of the large-scale geomorphology, with recent studies focusing mainly on small-scale structural features exposed in road cuts, quarries and excavations made for building foundations (Figure 1).

The paper tried to determine the zone's resistance, critical depth in excavation and in the end the role of faults in mechanical resistance of alluvium by comparing several pits in the zone of fault or the zone with no fault. For this purpose the impact of the neighboring building on the pit stability has been investigated in several locations in some part of coarse alluvium of northern Tehran. So

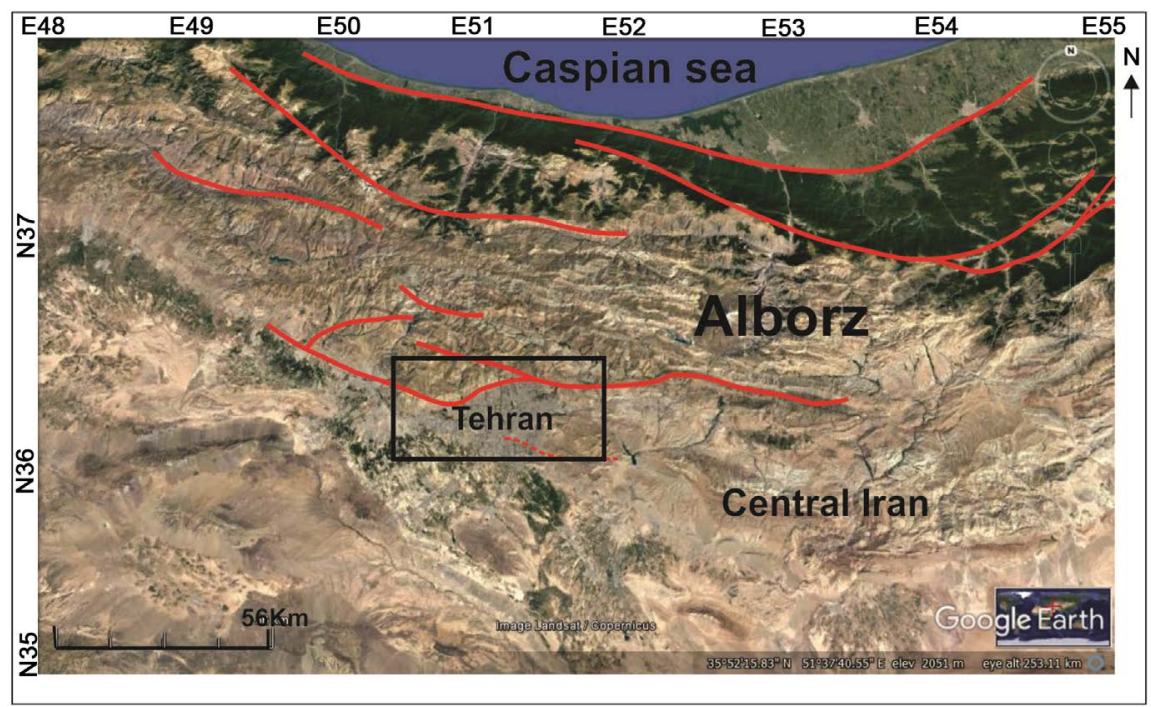

(a)

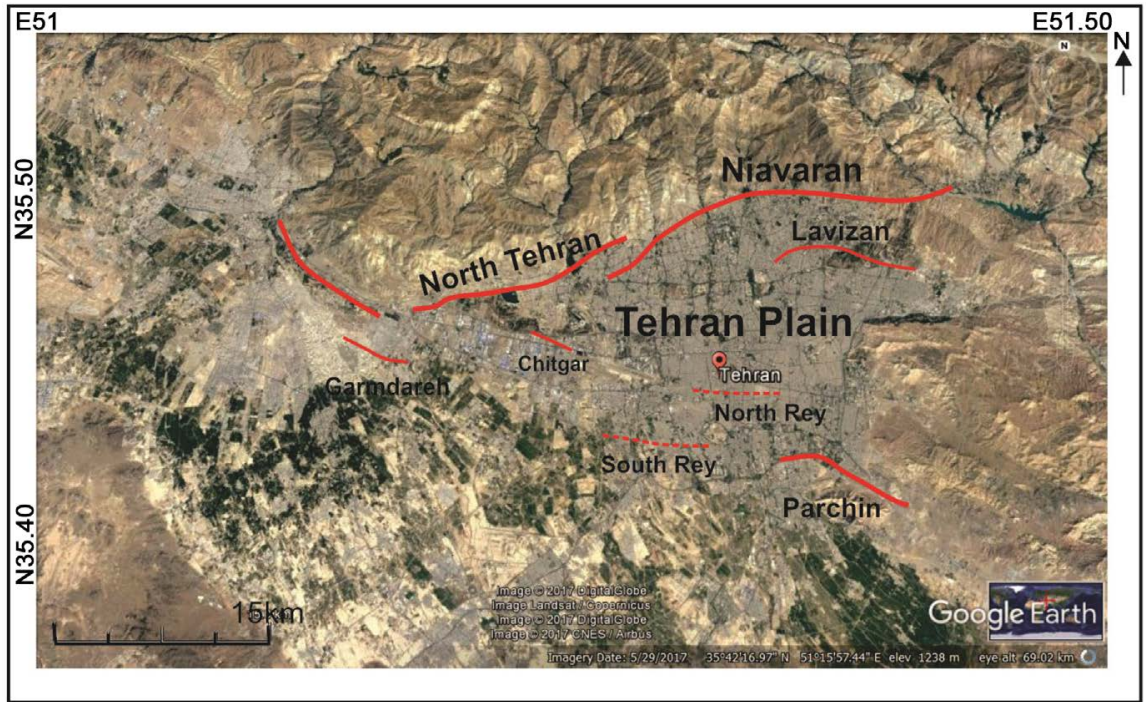

(b)

Figure 1. (a) Active faulting of the Alborz Mountains and the region around Tehran; (b) Google earth digital topography of the Tehran plain with active faults drawn in red. 
engineering methods such as numerical method and limit equilibrium with the help of software like FLAC 4.0.314 and SLIDE 6.020 were used to determine alluvium's resistance and the critical depth of excavation. Also the faults impact investigated on the resistance of alluvium [3].

\section{The Purposes and Methodology of the Studies}

\subsection{Purposes}

- Resistance determination of allovium

- Effect of fault on Tehran alloviums resistance

- Determine the critical depth of excavation.

\subsection{Research Methodology}

- Study of alluvium in different regions

- Comparison of alluvial resistance

- Pit stability analysis by numerical and equilibrium method

- Analysis with software of FLAC and SLIDE.

\section{Tectonic and Geologic Setting}

\subsection{Regional Tectonics}

Tehran lies at the foot of the Alborz belt, which is a seismically active region to the south of the Caspian Sea. The tectonic activity in the Alborz mountain range is caused both by the northward convergence of central Iran toward Eurasia, and also by the northwestward motion of the South Caspian Basin with respect to Eurasia (e.g. Jackson et al. 2002; Ritz et al. 2003, 2006; Copley \& Jackson 2006; Djamour et al. 2010; Mousavi et al. 2013). Oblique shortening in the Alborz is taken up by left-lateral strike slip faults within the interior of the range, and distributed thrusting on the northern and southern margins. The range is therefore being deformed by strain partitioning of the oblique shortening onto range-parallel left-lateral strike-slip and thrust faults (Jackson et al. 2002; Allen et al. 2003). The thrusts on the northern side principally dip to the south, whereas those in the south dip northwards (Stöcklin 1974). Frontal structures encroach upon the adjacent foreland basins: the South Caspian Basin in the north and along a less linear topographic front at the southern margin (Allen et al. 2003). To the South, deformation seems to extend beyond the piedmont area (Vernant et al. 2004). Present day N-S shortening and left-lateral shear across the Alborz occurs at $5 \pm 2 \mathrm{~mm} \cdot \mathrm{yr}^{-1}$ and $4 \pm 2 \mathrm{~mm} \cdot \mathrm{yr}^{-1}$, respectively (Vernant et al. 2004; Djamour et al. 2010).

\subsection{Active Faulting in the Tehran Region}

The NTF(North Tehran Fault) is a thrust that separates fluvial deposits of the Tehran plain from older, mostly Eocene, rocks of the central Alborz and defines the northern limit of the city (Figure 1 and Figure 2). It appears that the NTF experienced an early period of dextral shear, which was superseded by sinistral- 


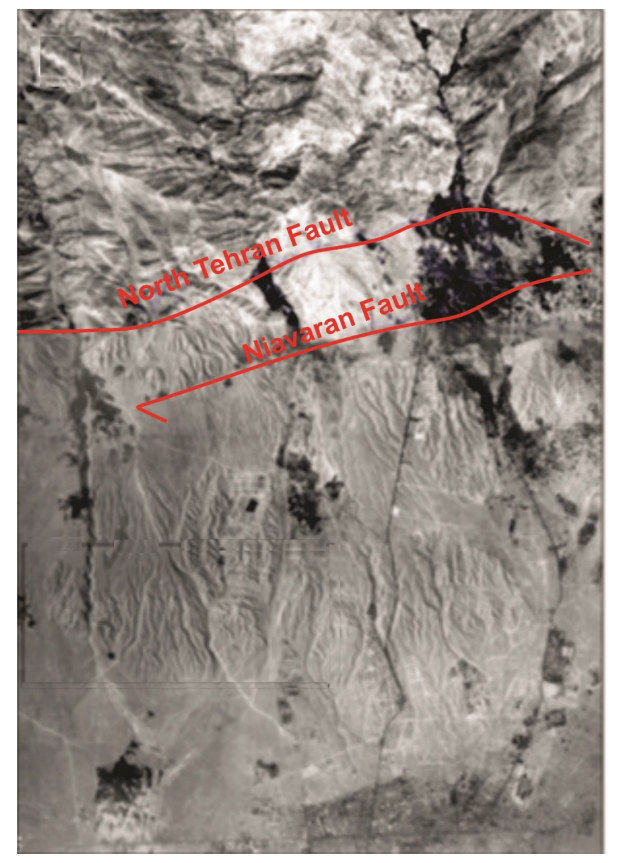

Figure 2. Geomorphic and structural interpretation. The north Tehran thrust follows the Alborz range-front.

oblique thrusting associated with NE-oriented shortening (Landgraf et al. 2009,) [4]. The surface trace of the NTF extends for about $70 \mathrm{~km}$ between $\sim 51^{\circ} 05^{\prime} \mathrm{E}$ and $\sim 51^{\circ} 50^{\prime} \mathrm{E}$. East of Tehran, it merges with the Mosha active left- lateral strike-slip fault (e.g. Solaymani Azad et al. 2011; Ghassemi et al. 2014). Ritz et al. (2012) uncovered six or seven surface rupturing events on the western NTF within the last $\sim 30 \mathrm{ka}$, with magnitudes that they estimate at 6.1 to 7.2 , and an average slip-rate of $\sim 0.3 \mathrm{~mm} \cdot \mathrm{yr}^{-1}$. They state that the two most recent events in their trench may correspond to the 312-280 B.C. and 1177 A.D. historical earthquakes. See Figure 1 for their trench location. The eastern extent of present-day activity on the NTF is debated. From a study near the eastern end of the NTF, Trifonov et al. (1996) concluded that activity stopped by the Mid-Late Pleistocene. They also conclude that a fault system south of the NTF (the Niavaran fault, Figure 1 and Figure 3) is younger. Abbassi \& Farbod (2009), and Solaymani Azad et al. (2011) also suggest that the eastern NTF is inactive, with activity now transferred southwards to the Niavaran fault. Several structures are visible in the alluvial plain $\sim 5-10 \mathrm{~km}$ south of the NTF and Niavaran faults (Figure 1). The Lavisan and Qeytarieh anticlines are the easternmost of these structures [5]. The anticlines correspond to elongate NNW-SSE ranges of low hills, which have steep escarpments on their northern margins. Geological cross-sections show asymmetric folding, with steep northern limbs and gently dipping southern limbs. The Pardisan anticline (the focus of our paper) is the next fold segment to the west, and has an overall vergence to the south (see details in Section 3). Further west, the Chitgar and Garmdareh anticlines are manifest in the landscape as ranges of low hills (Figure 1). The folds appear to be in a left-step- 


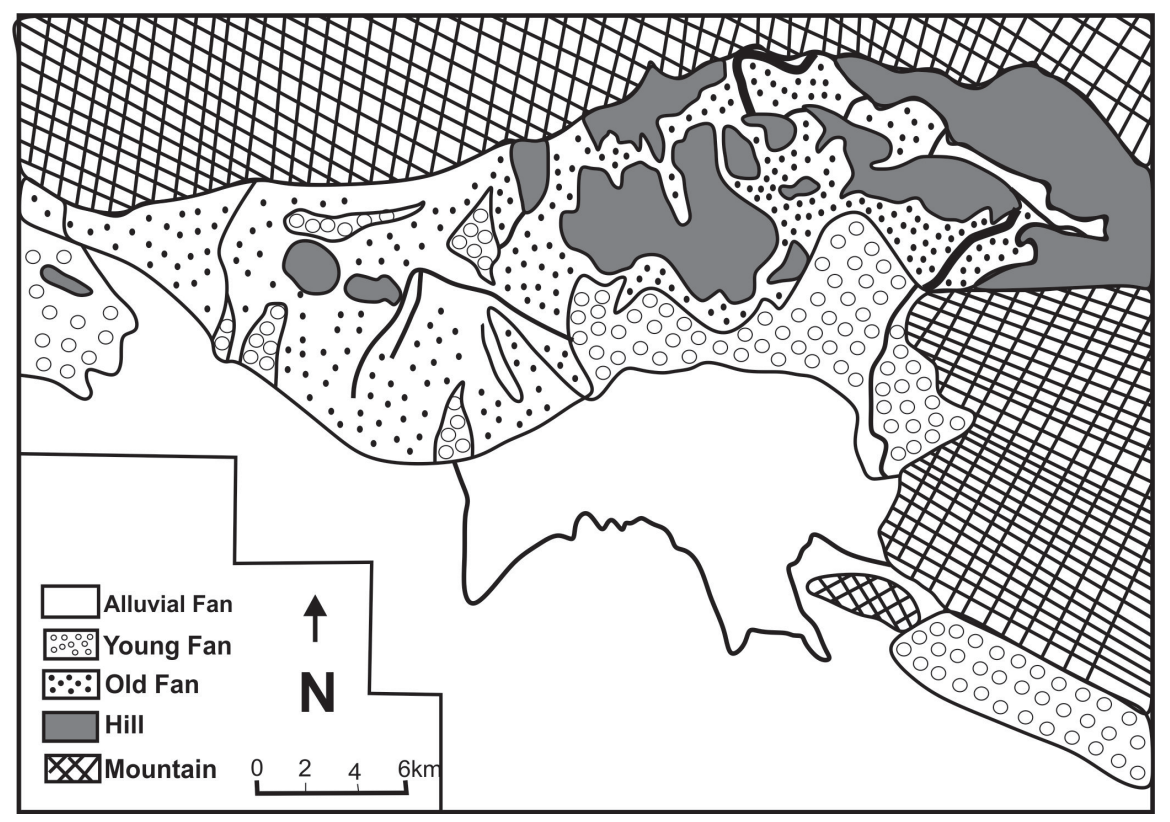

Figure 3. Tehran morphological map, distribution of different morphological units shown on the map (Cheshomi and et al., 1385).

ping en-echelon arrangement, which may indicate a component of left lateral strike slip across the zone of folding (e.g. Abbassi \& Farbod 2009). The eastern margin of the Tehran plain is defined by the Anti-Alborz range-front, whose southern edge is bounded by the Parchin active thrust (Figure 1).

\subsection{Geological of Tehran Alluvium}

Alluvial deposits of Tehran, researched by Geological Survey. the first time Rieben in 1955 studied Alluvial sediments southern of the Alborz based on stratigraphic characteristics, and these deposits divided to four formations known as A, B, C and D [6]. Among them A deposits are older than other and D is the newest deposits. This division Rieben, Was the basis for further studies and since then have not been major changes in this classification [7] [8]. The Sedimentology Properties of Tehran alluvial indicates that these sediments are, resulting from seasonal rivers which since the Late Pliocene so far, have originated from southern slopes of the Alborz Mountains. Specifications stratigraphy, lithology, morphology and age alluvial deposits Tehran cause that the deposits can be divided into separate wards. Evaluate the alluvial deposits of Tehran and about the impact on their orogenic phase shows that due to not knowing the exact age of the alluvial deposits, time of occurrence of these phases is not clear. In the first phase of orogenic deposits are alluvial formations A folded. In the second phase of the orogeny was series $B$, with a slope of 5 to 10 degrees layers. This orogenic phase of the event has been, 50,000 years ago. Formation C is on the B series, with horizontal stratification. At the moment the main problem to clarify the geological problems and to identify the contact lines different formation of $\mathrm{Qu}$ aternary in the area south of Tehran, of the earth's surface is covered by urban 
areas and facilities Which in total makes it difficult to identify these formations [9] [10]. The only important information will be used to identify them, the result of excavations in the city [11].

\subsection{Tehran Plain Geomorphology}

Tehran plain formed of alluvial deposits, Old and Young and hills with gentle slopes [12]. For a real understanding of the distribution of the units used of Figure 3, in Table 1 it is shown the different position of each type of deposits.

Regions of 16, 17, 19 and 20 completely and the majority of regions 10, 11, 12, 14, 15 and 18 are located in the alluvial plains. Regions major area of 1, 4, 5, 9, 21 covered old alluvial fan. Most of the regions 7, 8, 13 and parts of regions 1, 2, 3, 4, 5, 6 and 22 covered alluvial fans young and hills respectively.

As be seen in the map, southern areas of Tehran city is stable more than north of Tehran [13] [14].

\section{Previous Studies}

Amini in 1373 investigated the geotechnical characteristics of Quaternary sediments in Tehran Plain and basis of these studies identified Tehran alluvium distribution [15].

Jafari and colleagues in the years of 1376 and 138, investigated seismic geotechnical microzonation in Tehran area [16].

Asghari 1381, assessed concrete impact on the shear strength of Tehran's alluvium based on field tests and triaxial tests.

Cheshomy and colleagues in 1384, examined geological and geotechnical studies the path of Tehran's metro in line 3 and 7 and the basis of surface data proposed geological profile [17] [18].

Fakher and colleagues in 2007, investigated alluvial coarse-grained and they added geotechnical characteristics to geological classification in Tehran area. In this study, they considered the Rieben classification and added engineering parameters of $\mathrm{A}, \mathrm{C}$ to this category.

Table 1. Expansion of Tehran alluvium across different morphology (Cheshomi \& et al.).

\begin{tabular}{|c|c|c|c|c|}
\hline considerations & $\begin{array}{l}\text { Formation of } \\
\text { protrusions }\end{array}$ & $\begin{array}{l}\text { Average } \\
\text { gradient } \\
\text { (Degree) }\end{array}$ & $\begin{array}{l}\text { Altitude } \\
\text { (m) }\end{array}$ & $\begin{array}{c}\text { Morphology } \\
\text { unit }\end{array}$ \\
\hline $\begin{array}{c}\text { It seen in the mountains } \\
\text { north of Tehran }\end{array}$ & $\begin{array}{l}\text { Karaj Formation } \\
\quad(\text { tuff, ...) }\end{array}$ & $30-50$ & 1800 & Mountain \\
\hline $\begin{array}{l}\text { Height of Saadat Abad, } \\
\text { Tarasht \& Abas abad. }\end{array}$ & A \& B Formation & $\begin{array}{l}20-30 \text { (hill) } \\
30-40 \text { (foot) }\end{array}$ & 1500 & Hill \\
\hline $\begin{array}{c}\text { Plain of Evin, } \\
\text { Tajrish, Niavaran, ... }\end{array}$ & C Formation & $5-10$ & $1000-1500$ & $\begin{array}{l}\text { Old } \\
\text { Fan }\end{array}$ \\
\hline $\begin{array}{l}\text { Stream, old and } \\
\text { new river routes }\end{array}$ & $\begin{array}{c}\text { D Formation } \\
\text { (Coarse-grained) }\end{array}$ & less than 5 & $1100-1400$ & $\begin{array}{l}\text { Young } \\
\text { Fan }\end{array}$ \\
\hline South of Tehran & $\begin{array}{l}\text { D Formation } \\
\text { (Fine-grained) }\end{array}$ & Smooth & $1000-1100$ & Plain \\
\hline
\end{tabular}


Ghafuri in 1388, studied A and C alluvial ability to vertical excavation adjacent to a neighboring building and he researched on critical depth approach based on two criteria limit equilibrium methods and criteria deformation. Finally, he investigated vertical deep critical depth according to deformation criteria and effect of tension crack.

Rashidi in 1389, studied structural analysis and fault Morphotectonics in north of Tehran, in the range of Lavasan to Niyavaran [19].

\section{Formations around the Niavaran Fault}

Formation around Niavaran fault are Karaj Formation and Hezardareh. Part of the fault passes through the Hezardareh Formations. It includes conglomerate with interlayers of sandstone and clay. The age of Hezardareh conglomerate is upper Pliocene- lower Pleistocene (Figure 4).

\section{Discussion}

Regarding the relationship between faults, area alluvium and depth of excavation, Research was conducted about the fault of Niavaran in Saadatabad area to Niyavaran (Figure 4 and Figure 5). According to the engineering parameters of Tehran alluvium and using the software FLAC and SLIDE and roofs stable formula, for the first time, excavation critical depth calculated in this area (Figure 6 and Figure 7).

Niavaran fault length of $13 \mathrm{~km}$ and along earst northeast-west Southwest seen about a mile south of the thrust of Tehran north and parallel to that of Saadat Abad, Farahzad and Aghdasieh. In north of Aghdasieh, is seen the left lateral displacement about 600 meters in aerial photos. In the east, the thrust is divided into two branches and the southern branch goes to the Bahai Gardens. In the west, Western extension disappears in Farahzad young alluvial. In the west of Farahzad river There is a small thrust which may be in the western Niavaran thrust. In this case, the total length of this fault is 13 to $18 \mathrm{~km}$.

The mechanism of this fault is thrust and the northern part of Saadat Abad, Shemiran subsidence on the Evin, Tajrish and Niavaran [19].

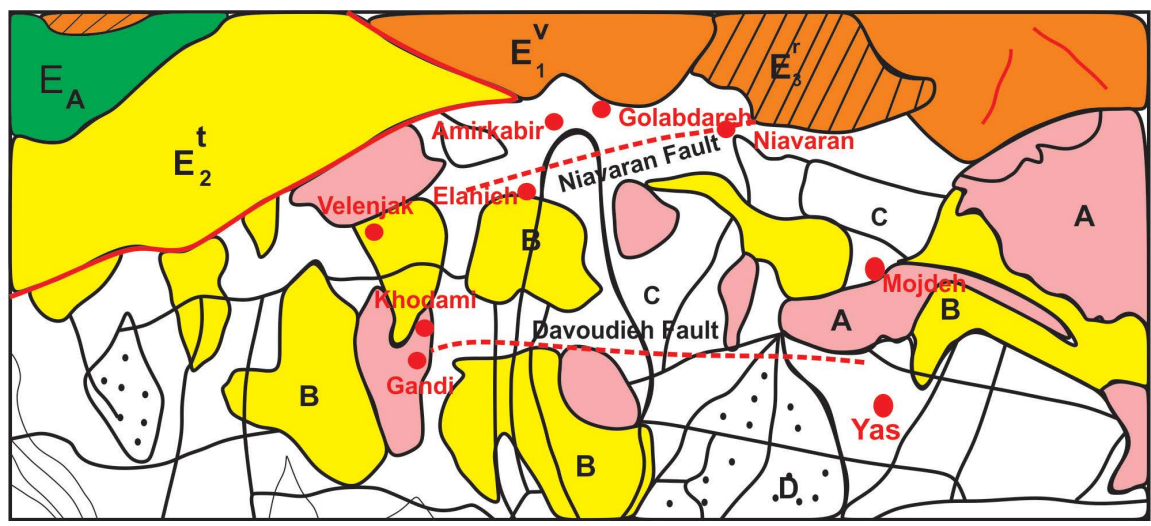

Figure 4. There exponential sections on the Tehran geological map with scale of 1:130,000 (Jafari, 1381). 


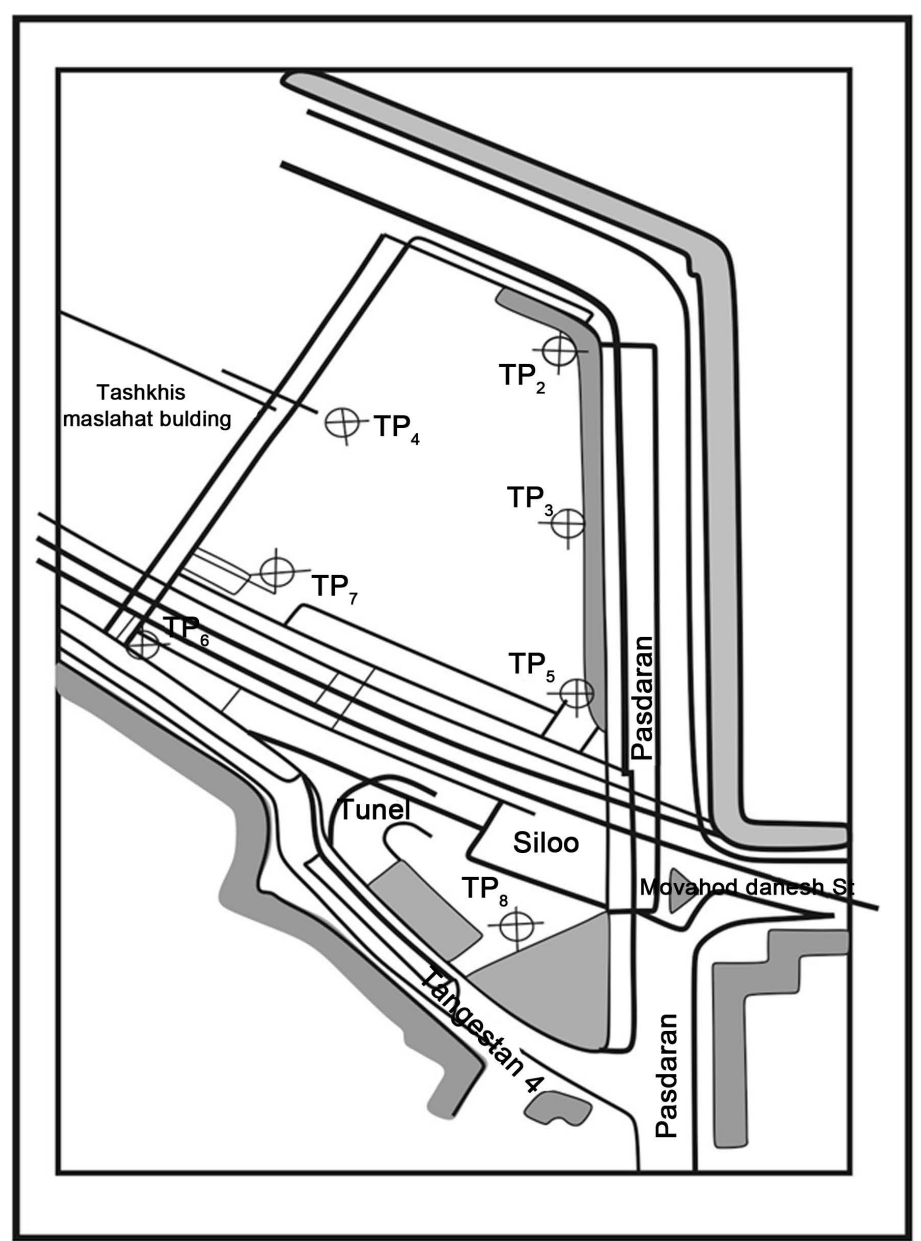

(a)
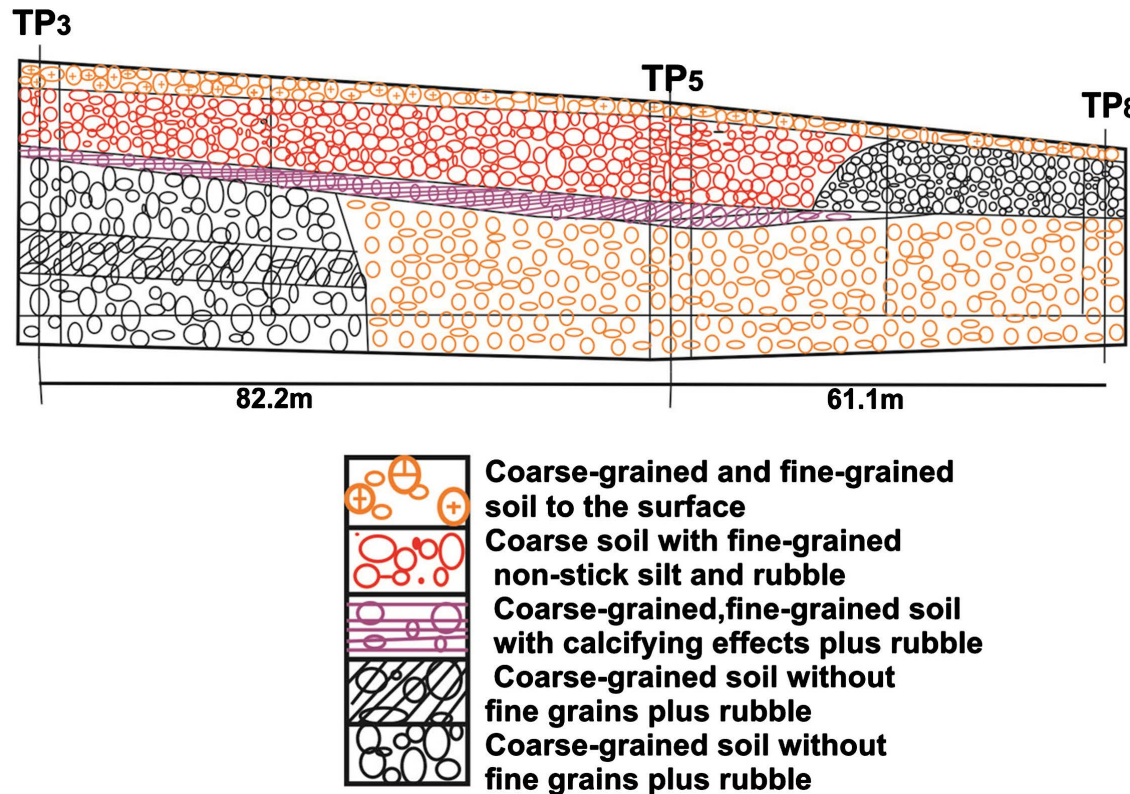

000080 a 100000

$000000 \%$

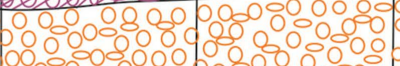

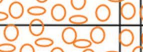

|

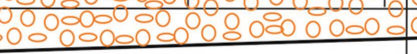

61.1m

Coarse-grained and fine-grained

soil to the surface

Coarse soil with fine-grained

non-stick silt and rubble

Coarse-grained,fine-grained soil

with calcifying effects plus rubble

Coarse-grained soil without

fine grains plus rubble

Coarse-grained soil without

fine grains plus rubble

(b)

Figure 5. (a) Deep aerial photographic with boreholes drilled manually studied $\left(35^{\circ} 48^{\prime} 20.82^{\prime \prime} \mathrm{N}, 51^{\circ} 28^{\prime} 17.78^{\prime \prime}\right.$; (b) profile of section $\mathrm{TP}_{3}, \mathrm{TP}_{5}, \mathrm{TP}_{8}$. 


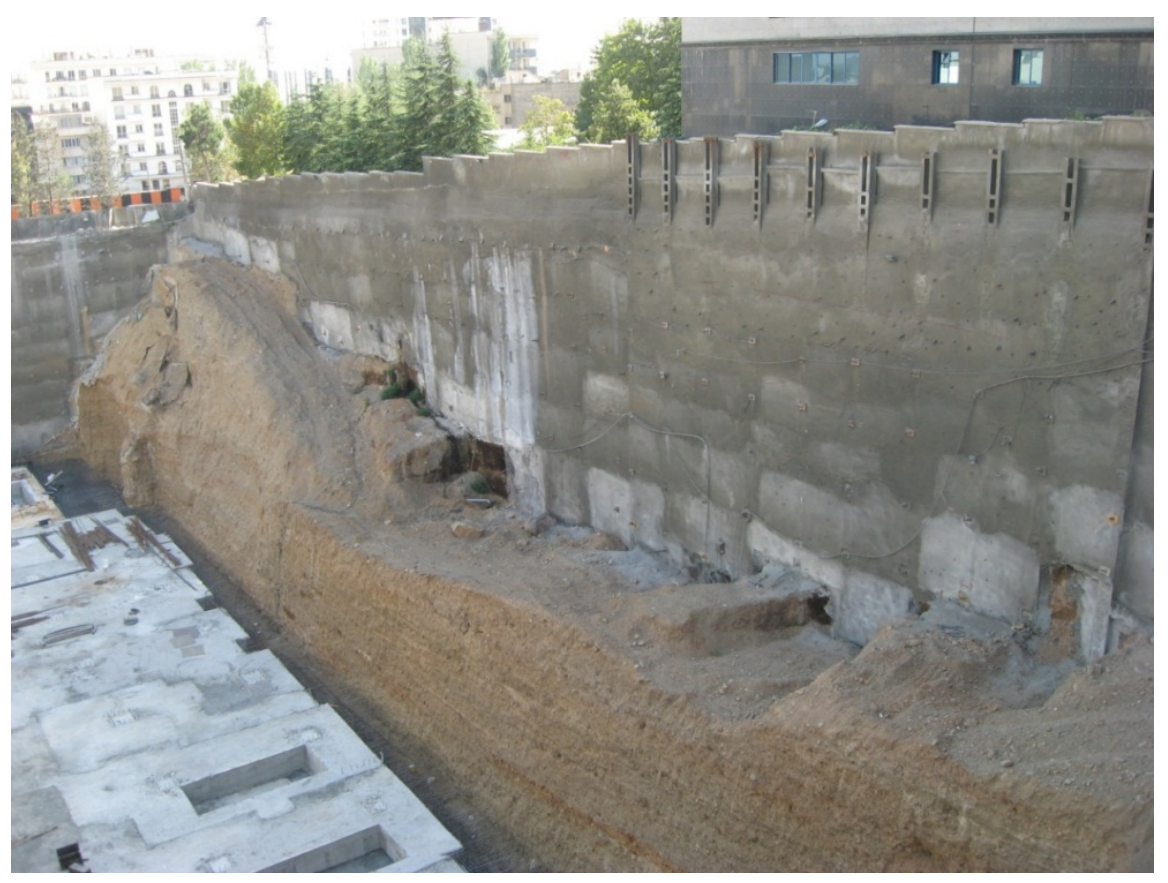

Figure 6. Niavaran deep wall of the North West, view to the north $\left(35^{\circ} 48^{\prime} 21.84^{\prime \prime} \mathrm{N}\right.$, $\left.51^{\circ} 28^{\prime} 15.58^{\prime \prime} \mathrm{E}\right)$.

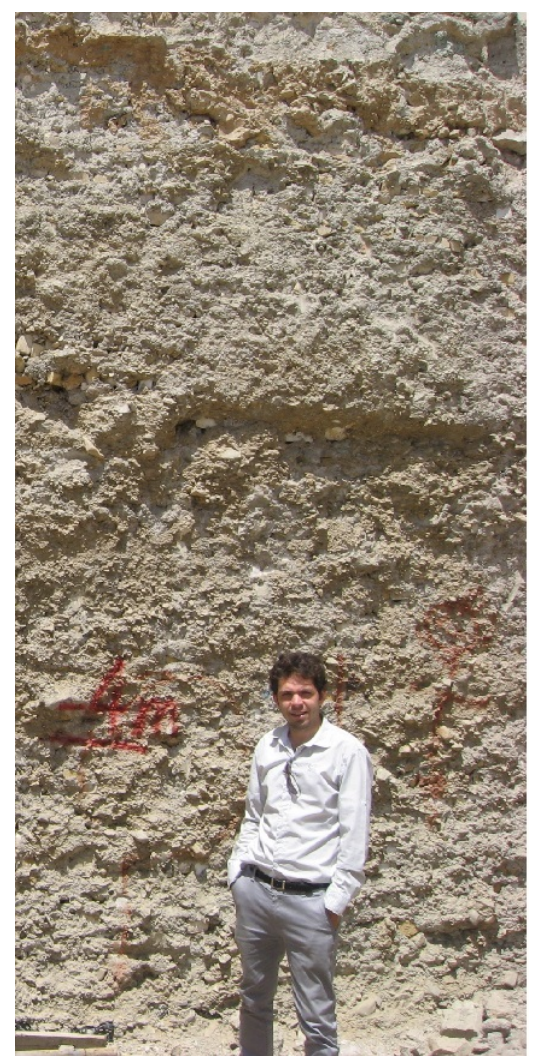

Figure 7. C alluvial in Niavaran fault with high resistance.

In these areas, despite the alluvial basement, when in an earthquake there has been high destruction (Table 2). 
Table 2. Critical depth excavation in the area with the fault and without fault.

\begin{tabular}{|c|c|c|c|c|c|c|}
\hline \multicolumn{4}{|c|}{ depth critical excavation $(\mathrm{m})$} & \multicolumn{2}{|c|}{$\begin{array}{c}\text { Type } \\
\text { of alluvial }\end{array}$} & \multirow{3}{*}{$\begin{array}{l}\text { deep } \\
\text { Name }\end{array}$} \\
\hline \multicolumn{2}{|c|}{$\begin{array}{l}\text { The case of the } 5 \text {-storey building at } \\
\text { a distance of } 3 \text { meters from the Deep }\end{array}$} & \multicolumn{2}{|c|}{$\begin{array}{l}\text { The burden of } \\
\text { neighboring states }\end{array}$} & \multirow{2}{*}{$\begin{array}{c}\text { In } \\
\text { terms } \\
\text { of } \\
\text { table }\end{array}$} & \multirow{2}{*}{$\begin{array}{l}\text { In } \\
\text { terms } \\
\text { of } \\
\text { Map }\end{array}$} & \\
\hline $\begin{array}{l}\text { Enkeraj properties } \\
\text { with } 1.5 \text { confidence }\end{array}$ & $\begin{array}{l}\text { Limit } \\
\text { equilibrium }\end{array}$ & $\begin{array}{l}\text { Numerical } \\
\text { Equilibrium }\end{array}$ & $\begin{array}{c}\text { Limit } \\
\text { equilibrium }\end{array}$ & & & \\
\hline $\begin{array}{l}\text { Length } 15 \mathrm{~m} \text {, dip } 20^{\circ} \text {, } \\
\text { the tensile strength of } 65 \mathrm{kN} \text {, } \\
\text { distance of } 1 \mathrm{~m}\end{array}$ & 10 & 6 & 10 & A & A & Khodami \\
\hline $\begin{array}{l}\text { Length } 15 \mathrm{~m} \text {, dip } 20^{\circ} \text {, } \\
\text { the tensile strength of } 60 \mathrm{kN} \text {, } \\
\text { a distance of } 1 \mathrm{~m}\end{array}$ & 13 & 8 & 15 & A & A & Gandi \\
\hline $\begin{array}{l}\text { Length } 15 \mathrm{~m} \text {, dip } 15^{\circ} \text {, } \\
\text { the tensile strength of } 80 \mathrm{kN} \text {, } \\
\text { a distance of } 9.0 \mathrm{~m}\end{array}$ & 3 & 3 & 4 & - & B & Velenjak \\
\hline $\begin{array}{l}\text { Length } 16 \mathrm{~m} \text {, dip } 15^{\circ} \text {, } \\
\text { the tensile strength of } 80 \mathrm{kN} \text {, } \\
\text { a distance of } 9.0 \mathrm{~m} .\end{array}$ & 1.5 & 2 & 1.5 & - & B & Lavizan \\
\hline $\begin{array}{l}\text { Length } 16 \mathrm{~m} \text {, dip } 15^{\circ} \text {, } \\
\text { the tensile strength of } 80 \mathrm{kN} \text {, } \\
\text { a distance of } 8.0 \mathrm{~m} .\end{array}$ & 3 & 3.5 & 3 & $\mathrm{C}$ & $\mathrm{C}$ & Golabdareh \\
\hline $\begin{array}{l}\text { Length } 16 \mathrm{~m} \text {, dip } 15^{\circ} \text {, } \\
\text { the tensile strength of } 80 \mathrm{kN} \text {, } \\
\text { a distance of } 8.0 \mathrm{~m} .\end{array}$ & 3 & 3.5 & 3.5 & $\mathrm{C}$ & $\mathrm{C}$ & Elahieh \\
\hline $\begin{array}{l}\text { Length } 16 \mathrm{~m} \text {, dip } 15^{\circ} \text {, } \\
\text { the tensile strength of } 80 \mathrm{kN} \text {, } \\
\text { a distance of } 1 \mathrm{~m}\end{array}$ & 6 & 5 & 6 & $\mathrm{C}$ & $\mathrm{C}$ & $\begin{array}{l}\text { (Niavaran } \\
\text { Faulting) }\end{array}$ \\
\hline $\begin{array}{l}\text { Length } 16 \mathrm{~m} \text {, dip } 15^{\circ} \text {, } \\
\text { the tensile strength of } 80 \mathrm{kN} \text {, } \\
\text { a distance of } 9.0 \mathrm{~m} .\end{array}$ & 2 & 2.5 & 2 & $\mathrm{C}$ & $\mathrm{C}$ & Amirkabir \\
\hline $\begin{array}{l}\text { Length } 16 \mathrm{~m} \text {, dip } 15^{\circ} \text {, } \\
\text { the tensile strength of } 85 \mathrm{kN} \text {, } \\
\text { a distance of } 8.0 \mathrm{~m} .\end{array}$ & 1 & 2 & 1.5 & $\mathrm{C}$ & $\mathrm{C}$ & Yasalghadir \\
\hline
\end{tabular}

\section{Conclusion}

According to data analysis and comparisons of alluvial, we obtained the following results:

- A alluvium has superior resistance in comparison to B and C alluviums from this aspect of mechanical properties.

- By studying C alluvium in areas of Golabdareh, Elahieh, Amirkabir, Alghadir and finally Niavaran, it was found that $\mathrm{C}$ alluvium has the least resistance, but significant resistance observed in Niavaran.

- According to geological features of Niavaran deep, faulting causes to create a crush zone, cementation increases in this part of the $\mathrm{C}$ alluvium compared to other sectors and so, critical depth of excavation increases in this part of the $\mathrm{C}$ alluvium more than other sectors. We have shown that, contrary to the 
impression, faulting increases soil resistance.

\section{Acknowledgements}

We thank the Geological Survey of Iran and Dr Manouchehr Ghorashi, Dr Mohsen Pourkermani that help me at all of the stage of preparing this article.

\section{References}

[1] Imanzadeh, J. (1389) Sustainability Analysis and Presentation of Excavation Pattern in Fine Grained Alluvial Soils of Tehran. Journal of Science, University of Tehran.

[2] Berberian, M., Jackson, J.A., Qorashi, M., Khatib, M.M., Priestley, K., Talebian, M. and Ghafuri-Ashtiani, M. (1999) The 1997 May 10 Zirkuh (Qaenat) Earthquake (Mw 7.2): Faulting along the Sistan Suture Zone of Eastern Iran. Geophysical Journal International, 136, 671-694. https://doi.org/10.1046/j.1365-246x.1999.00762.x

[3] Terzaghi, K. (1967) Soil Mechanics in Engineering Practice. Wiley, New York, 497523.

[4] Ghanbari, A. (1386) Study of the Modulus of Soil Elasticity in Alluvial South of Tehran. The Research Project Presented to the Research Vice-President of Tarbiat Moalem University of Tehran.

[5] Bishop, A.W. (1955) The Use of the Slip Circle in the Stability Analysis of Slope. Geotechnique, 10, 129-150. https://doi.org/10.1680/geot.1955.5.1.7

[6] Djamour, Y., et al. (2010) GPS and Gravity Constraints on Continental Deformation in the Alborz Mountain Range, Iran. Geophysical Journal International, 183, 1287-1301. https://doi.org/10.1111/j.1365-246X.2010.04811.x

[7] Rieben, E.H. (1966) Geologocal Observation on Alluvium Deposits in Northern Iran. Geological Organization of Iran, Report No. 9, 39.

[8] Rieben, H. (1955) The Geology of the Tehran Plain. American Journal of Science, 253, 617-639. https://doi.org/10.2475/ajs.253.11.617

[9] Engalenc, M. (1968) Contribution a la Geologie, Geomorphologie, Hydrologie de la Region de Tehran (Iran). C.E.R.H., 365 p.

[10] Habibi, M. (1385) Study of Mechanical Properties of Coarse Alluvial Deposits of Tehran Based on Usual Tests and Simple Mechanical Tools. PhD Thesis of Engineering Geology.

[11] Hosseini, A. (1389) Excavation near the Neighboring Building. Master's Thesis.

[12] Aghanabati, A. (1385) Geology of Iran. Third Print, 580 p.

[13] De Martini, P.M., Hessami, K., Pantosti, D., D’Addezio, G., Alinaghi, H. and Ghafory-Ashtiani, M. (1998) A Geologic Contribution to the Evaluation of the Seismic Potential of the Kahrizak Fault (Tehran, Iran). Tectonophysics, 287, 187-199.

[14] Nasekhian, A. (1388) Studying the Behavior of Diagonal Cavities in Conventional Recruiting in Tehran. Master's Thesis.

[15] Amini, M. (1373) Geotechnical Properties of Quaternary Sediments in Tehran Plain. Proceedings of the First International Quaternary Symposium, University of Tehran.

[16] Jafari, M., et al. (1381) Geotechnical Identification for Light Buildings in Tehran. The Second Construction Seminar in the Capital, North Seismic Zoning Report from the Point of View of the Site, International Institute of Seismology.

[17] Cheshomi, A., Fakher, A. and Khamehchian, M. (1387) Geology of Tehran Alluvials 
and Assessment of Rubin Classification for Engineering Geology Studies. Journal of Science, University of Tehran.

[18] Fakher, A., Cheshomi, A. and Khamechian, M. (2007) The Addition of Geotechnical Properties to a Geological Classification of Coarse-Grained Alluvium in a Pediment Zone. Quarterly Journal of Engineering Geology and Hydrogeology, 40, 163 174. https://doi.org/10.1144/1470-9236/06-029

[19] Rashidi, S. (1392) Structural Analysis and Morphotectonics of North Tehran Fault in Lavasan to Niavaran Range. Master's Thesis, Islamic Azad University.

Submit or recommend next manuscript to SCIRP and we will provide best service for you:

Accepting pre-submission inquiries through Email, Facebook, LinkedIn, Twitter, etc. A wide selection of journals (inclusive of 9 subjects, more than 200 journals) Providing 24-hour high-quality service User-friendly online submission system Fair and swift peer-review system Efficient typesetting and proofreading procedure Display of the result of downloads and visits, as well as the number of cited articles Maximum dissemination of your research work

Submit your manuscript at: http://papersubmission.scirp.org/

Or contactojg@scirp.org 